\title{
The South African TRC as Neoliberal Reconciliation: Victim Subjectivities and the Synchronisation of Affects
}

\begin{abstract}
This article brings new insights from critical neoliberalism studies into dialogue with recent critical human rights scholarship to develop a theoreticallydriven analysis of South Africa's post-apartheid transition. With South Africa's post-apartheid settlement becoming increasingly fragile, there is a growing need to revisit the purported miracle of transition. Recognising this need, the article critically explores the relationships between the social transformations wrought by South Africa's neoliberal transition and the parallel processes of the country's Truth and Reconciliation Commission (TRC). Understanding neoliberalism as a modality of governing concerned with producing subjects as individualised enterprises, I analyse the TRC as a mechanism which supported this objective by 'de-collectivising' the social and making it more amenable to the demands of postapartheid neoliberalism. To do so, I explore how the TRC's use of public testimony and mass-media broadcasting displaced collective struggles against apartheid with a range of subjectivities organised around human rights victimhood. The overall effect of the TRC, I conclude, was to constitute post-apartheid society as a thin, individualised, and ultimately fragile 'community of emotion' that comfortably sits within the limits of South African neoliberalism. I conclude by reflecting on the implications of this analysis for other transitional contexts.
\end{abstract}

Key Words: South Africa; human rights; transitional justice; neoliberalism; subjectivity; reconciliation.

\section{Introduction}

Since the 2008 global financial crisis a growing field of critical neoliberalism studies has emerged as a response to the failures of neoliberal globalisation, which, whilst seemingly discredited by the crash, also stubbornly lives on both as a globally hegemonic set of economic policies and a 'way of being' rooted in a 'common sense' that has proven difficult to shake (Mirowski, 2013). A key objective of critical neoliberalism studies has been to better define a term which often seems like a loose and shifting signifier (Brown, 2015). This has been achieved through a historical mapping of neoliberalism's origins in an intellectual project of the early $20^{\text {th }}$ century which came to material fruition in the late70s (Foucault, 2008; Dardot \& Laval, 2013), and theoretical discussions that identify the key characteristics of a hegemonic socio-political and economic project, that is nonetheless varied across space and time (Brown, 2015; Davies, 2014).

Although not directly informed by this work, 'neoliberalism' is also becoming an important concept in critical human rights scholarship. Scholars are now interrogating the interrelations between neoliberal globalisation and human rights by situating their entanglements in both historical and theoretical perspective (Marks, 2013; Moyn, 2014; Odysseos, 2010). Furthermore, a nascent body of scholarship has now begun to unpack these interrelations in the study of transitional justice (Franzki \& Olarte, 2014; Gready, 2011). Adding to these urgent, ongoing debates, this article brings work from critical neoliberalism studies into further dialogue with critical human rights and transitional justice scholarship, showing the utility of these approaches by bringing them to bear on 
under-theorised dimensions of the South African transition.

While South Africa's Truth and Reconciliation Commission (TRC) is well trodden in socio-legal scholarship (see: Christodoulidis, 2000; Moon, 2006; 2008), recent events have shown that South Africa is a politically urgent case that warrants fresh attention. The neoliberal trajectory of post-apartheid South Africa appears to be unravelling; growing, racialised inequalities (Finn et al., 2011) are now accompanied by social unrest. The 2012 Marikana massacre, in which a series of wildcat strikes in Marikana's platinum mines were met by the lethal violence of South Africa's police force (Alexander et al., 2012) is indicative of a considerable shift in the relationships between Black South Africans and their traditional political and economic institutions. Corruption scandals and a mounting electoral crisis now engulfing the ANC are further evidence of this shift. Taken together, these developments demonstrate a post-transitional reality markedly different from the vision articulated during the transition.

Considering this crisis, my aim is to re-examine the TRC as a constellation of practices central to legitimising and thus sustaining the trajectory of post-apartheid neoliberalism. Drawing insights taken from critical neoliberalism studies, I characterise neoliberalism as a project that has relied on practices of social, political, and economic 'decollectivisation' to support its broader objectives of reconfiguring both the social in the image of the market and the subject as an individualised entrepreneur. Using this schema as a way of understanding the social, political and economic dimensions of the transition, I then conceptualise the TRC as a set of practices that performs some of the political work of 'de-collectivisation' necessary to the broader imposition of neoliberalism in South Africa.

Noting the centrality of the TRC to the legitimacy and socio-cultural imaginary of the transition (Wilson, 2001), my argument is that the Commission responded to the challenges of neoliberal transition by constructing a singular 'collective memory' of the past, a narrative which re-articulated the meaning of 'apartheid' from a history of systemic violence and struggle to a 'conflict' marked by violence against suffering bodies. Articulated through human rights discourse, this narrative depoliticised apartheid by foregrounding the ethical rejection of physical violence over the politics of struggle against systemic violence. The efficacy of this narrative vis-à-vis neoliberalism, I argue, was in its capacity to transform subjectivity through affective practices. Such practices did the necessary work of dissembling and deactivating the political relations of the struggle in ways that prefigured and supported the individualising demands of South African neoliberalism.

Developing this theoretical exposition through a reading of TRC documents, testimonies, and secondary literature, the article examines the Commission's practices of 'truth telling', which could 'produce' individuals as human rights victims. I argue this production of subjectivity usefully dissembled prior political imaginaries through an ethics of reconciliation that venerated the suffering body. The article then turns to the TRC's use of mass-media broadcasting as a set of practices that are distinct but interrelated to truth-telling, and which also engender the production of new subjectivities. Drawing from the work of Paul Virilio (2012), I explore the ways in which mass-media practices engendered a 'synchronisation of affects' that established South Africa as a community of emotion through a shared sympathy for human rights victims and the cathartic performance of reconciliation. Taken together these practices prefigured the neoliberal transition by reconstituting the past in ways that produced subjects who are 
more amenable to the individualising, entrepreneurialising demands of post-apartheid neoliberalism.

\section{Human Rights and Neoliberalism}

Although the politics of human rights has often been contested (see: Brown, 2004; Odysseos and Selmeczi 2015; Wilson 2006), a growing literature has become concerned with the relationship between human rights and neoliberalism. Scholars have shown that the rise of the human rights movement and related practices cannot be easily disentangled from the rise of neoliberal globalisation in the late-70s, which signalled a turn to the now 'common sense' policies of privatisation and market deregulation that combine neoliberalism's overlapping principles of marketization and 'state-phobia'. ${ }^{1}$ Although this work has yet to fully engage with the insights offered by recent work from critical neoliberalism studies, it has developed several useful historical and theoretical resources.

A recent debate between Samuel Moyn (2012; 2014) and Susan Marks (2013) suggest that there are important historical and theoretical linkages between human rights and neoliberalism. Moyn (2012: 121) has shown that the rise of the human rights was a reaction to the broader political trends of this period, particularly the pessimism of the '70s whose oil shocks and social discontent birthed a loss of faith in the "programmatic endeavours' of both revolutionary communism and the welfarism of social democracy. For Moyn, human rights emerged in this context 'as a minimalist, hardy utopia,' whose emphasis on negative freedom from state coercion rather than affirmative programmes of social justice meant it could survive neoliberalism's 'harsh climate' (ibid.). Human rights, Moyn (2014) concludes, emerged as a powerless companion to the neoliberal revolution rather than one of its key protagonists.

For Marks (2013), however, the connection between neoliberalism and human rights should be made in more emphatic terms. Setting her own arguments in the history traced by Moyn, Marks argues that human rights usefully minimised the terrain of ethical social action, recasting activism in ways that enabled neoliberal globalisation to flourish. In contexts where the 'effects of neo-liberal construction began to bite,' the adoption of human rights frameworks confined criticism 'to the denunciation of abuses, leaving unchallenged the conditions in which those abuses had become possible and even, in some sense, rational,' (225-226). The theoretical implication is that human rights became what Foucault (1998: 93) called a new 'grid of intelligibility' through which 'injustice' was largely conceptualised as physical cruelty at the expense of largely abandoning or bracketing off political conceptions of socioeconomic and structural violence.

These arguments are also reflected in a recent discussion between Philip Alston (2017a; 2017b) and Ron Dudai (2017) about the failings of the human rights movement. For them, the movement's focus on civil and political rights has resulted in a failure to confront the forms of inequality and social exclusion caused by neoliberal globalisation. In response, the authors advocate for a turn towards social and economic rights as a means of combatting a 'new or resurgent neoliberal agenda,' (Alston, 2017a, p. 10). Indeed, Dudai (2017: 19) strongly argues that the human rights movement must now

\footnotetext{
${ }^{1}$ Although, as I will point out later, neoliberalism's 'state-phobia' is not as straightforward as it is often thought.
} 
move beyond the hardy minimalism it adopted in the 1970s and explicitly argue against inequality, the free market, and, most radically, think 'of social and economic rights in class terms.' In this respect, Dudai plots a route forward for human rights rooted in a critique of precisely the grid of intelligibility traced by Moyn and Marks.

Criticisms of the absences produced by human rights find their own iterations within the study of transitional justice (TJ). Emerging out of the human rights movement, TJ crystallised in the " 80 s through a series of experiments with institutional practices such as criminal trials and truth commissions designed to address the legacies of societies making the transition from authoritarian rule and/or conflict to liberal democracy (Arthur, 2009). It is now a 'global project' (Nagy, 2008) of global governance and is embedded within policy programmes of international institutions such as the UN and the World Bank. TJ coheres around the assumption that transitioning to liberal democracy is an unalloyed good and that its mechanisms normatively support transitions by reestablishing the rule of law and fostering reconciliation.

Several scholars have already criticised TJ because it has promoted civil and political rights at the expense of overlooking socioeconomic issues that are relevant to transitions (Evans, 2016; Gready and Robbins, 2014: 342). Zinaida Miller (2008) has argued that by occluding socio-economic issues in transitional discussions, TJ creates and perpetuates silences and invisibilities. For Ismael Muvingi, (2009) this is especially problematic; unaddressed socioeconomic problems may constitute 'powder kegs' that threaten to explode into new rounds of violence if they remain ignored. Others make an implicit nod to neoliberalism by arguing that $\mathrm{TJ}$ has become institutionalised in the present paradigm of global governance because its focus on civil and political rights neatly dovetails with the latter's market-oriented approach (Gready and Robbins, 2014; Sriram 2014). Importantly, for scholars like Tshepo Madlingozi (2010: 212), the institutionalisation of $\mathrm{TJ}$ also means that it can be understood as part of a racialised and neo-colonial project, aimed at 'reconstructing Third World states in Western liberal democratic terms.'

But it is Franzki and Orlate (2014) who have given the most explicit and sustained analysis of its relationship to neoliberalism. For them, TJ is circumscribed by its commitment to political liberalism, and prioritises the task of legitimising democratic political institutions over socioeconomic concerns. Consequently, it has a habit of 'barring questions concerning democratic control of the economy from political debate and marginalising claims for social equality,' (206). In ignoring these issues, Franzki and Orlate argue, $\mathrm{TJ}$ has enabled neoliberal globalisation because it 'has turned a blind eye to the economic counterpart of the spread of actually existing liberal democracies, namely the advancement of 'globalisation' largely following neo-liberal parameters,' (217).

While the literature outlined above shares a concern with the invisibilities rights practices produce, other work has provided a very different lens with which to view this problem by rooting itself in a Foucauldian approach to neoliberalism. Drawing from Foucault's Birth of Biopolitics (2008), Louzia Odysseos (2010) argues that neoliberalism is driven by the impulse to 'not govern too much' and is concerned with limiting state interventions to encourage a 'free' and 'self-governing' subject. Supporting this ambition, Odysseos argues that the human rights project engenders practices that produce subjects as homo juridicus, the holder of rights, a correlate of neoliberalism's free and selfgoverning subject. By producing homo juridicus, Odysseos argues, human rights practices become a form of 'ontogenesis' that maturates individuals into self-governing 
subjects by encouraging them to seize their freedom. Odysseos' work is notable insofar as it shows the ways in which human rights 'actively' supports neoliberalism through the production of subjectivity. This approach has been critically developed by other authors to examine the political work of South African shack-dwellers (Selmeczi, 2015) and the neoliberal function of indigenous rights (Lindroth, 2014).

In different ways, the theoretical perspectives outlined here provide fertile ground upon which a critical analysis of the South African TRC is possible. Nevertheless, these perspectives can be substantially developed by bringing them into closer relation with insights from critical neoliberalism studies. This undertaking provides the conceptual basis for my re-reading of the South African transition that aims to have implications for the study of other human rights practices and TJ institutions in future. To pursue this trajectory, the next section outlines the key ideas that critical neoliberalism studies can contribute to these debates.

\section{What is Neoliberalism?}

Critical neoliberalism scholars have sought to define neoliberalism as a modality of governing which has its intellectual origins in the work of variety of thinkers and schools of thought, from the European 'Ordoliberals' to the Chicago School in the United States (See: Brown, 2015; Dardot \& Laval, 2013; Mirowski, 2013). For these authors, 'actuallyexisting' neoliberalism materialised in the late-1970s as a globalised mode of governing that would be implemented and maintained by both international financial institutions (such as the World Bank and the IMF) and national governments, manifesting itself as policies of privatization, and the diffusion of 'the market' into evermore domains of 'the social'.

A distinguishing feature of these studies is that they avoid the difficulties of defining neoliberalism as any one set of policy prescriptions by conceptualising it as an overarching set of objectives that can account for policy variances 'across space and time' (Brown, 2015: 20). Critical scholars stress that neoliberalism is a modality of governing which acts upon individuals to foster particular conducts underpinned by market assumptions. It is defined by a pernicious economism, which 'disseminates the model of the market to all domains and activities,' in order that 'it configures human beings exhaustively as market actors,' (ibid: 31 ). In this respect, neoliberalism takes both the social realm and the subject as its locus of operation, rather than a 'separate' sphere of the economy cleaved from social questions.

Undoubtedly, these insights share some conceptual resonances with Odysseos' analysis especially because they are also inspired by Foucault's Birth of Biopolitics (2008) and its concern for how economic practices shape human subjectivity. There are, nonetheless, significant divergences. As opposed to Odysseos' 'free' and 'self-governing' subject, critical neoliberalism scholarship emphasises that neoliberalism aims to produce individuals as competitive enterprises, and foregrounds competitive individualism rather than 'self-government' even if the latter is entangled with the former. As Foucault (2008: 224-229) points out, neoliberalism's entrepreneurial subject is rooted in a reconceptualisation of the worker as "human capital". In this framework, 'Classical' and Marxist ideas of the worker and labour time are upended by the transformation of all human activities, abilities and skills such as family life and education into possible investments in oneself - capitals - that can make one more competitive in the labour 
market and increase one's income stream. Neoliberalism is concerned with producing a subject who is defined by 'the logic of the enterprise as a unit of production engaging in competition with others' (Dardot and Laval, 2013: 100).

Accordingly, neoliberalism is more than simply a set of economic policy prescriptions that were normalised under the banner of the 'Washington Consensus'. Rather, specific policies are recast as a set of tactics with which to proliferate market competition. But these tactics serve the overarching strategy of producing the subject as an enterprise well-adapted to competitive markets. In this sense, neoliberalism reconceptualises the liberal commitment to individualism under the auspices of market competition. This is central to the intellectual projects of pioneering neoliberal thinkers that began in the early $20^{\text {th }}$ century (ibid: 49-50, 64-67), and underpins the "lived" neoliberal policies that bend global society to the logic of the market.

A crucial contribution of critical neoliberalism studies has been to show that the market individualism undergirding neoliberal thought was concertedly anti-collectivist in its origins and, in practice, has given birth to a range of practices designed to decollectivise the 'social'. Indeed, Dardot and Laval (2013: 49) have shown that early neoliberals were very concerned with creating a project that would combat the growing socio-political and economic collectivism represented by trade unions and radical politics. Early neoliberals were preoccupied with decollectivising strategies that could 'block the trend towards policies of redistribution social security [...] a trend perceived as a breakdown leading straight to collectivism.'

For its early thinkers, this meant that the 'neo' of neoliberalism also introduced the need for a robust socio-political order that could defend principles of individualism and market competition. Not quite the state-phobic caricatures that circulate in popular discussion, neoliberals acknowledge the need for 'state action,' to 'continually restore the conditions for free competition, which was threatened by social logics that tended to jam it, in order to ensure the "victory of the fittest",' (ibid: 61). The state is thus a crucial protagonist of neoliberal strategy, but its interventions are not 'redistributive'; they only play a role in organising, regulating, and defending market competition.

Within the reality of 'lived' neoliberalism, the requirements of de-collectivisation have often necessitated political and legislative attacks on unions and labour organisations. For example, Thatcherism in Britain aimed to destroy the economic and political base of the working class through the drastic reduction of trade union power (Ibid: 173). Similarly, Pinochet's authoritarian violence against leftists and labour organisations was a means of eradicating social, political and economic forms of collectivisation in Chile. Such tactics took their aim at collectivised economic \& political relations as part of a greater strategy of creating 'generalised competition, including in the order of subjectivity' (Ibid.: 153). Weakening collective solidarity was imperative to the success of co-emergent practices designed to 'produce' individuals as enterprises, such as 'the creation of individual savings for retirement, purchase of one's home, long-term investment in stock market equities.' (Ibid.: 157).

I want to argue that the relationship between the decollectivizing work of 'creative destruction' and the production of entrepreneurial subjectivity delineated above identifies and articulates something important about the function of the TRC in relation to the entrepreneurialising objectives of South African neoliberalism, with important implications for the broader human rights movement and its mechanisms of TJ. My point, however, is not that the TRC should be straightforwardly conflated with the authoritarian 
violences of Pinochet and Thatcher but that it performs a form of decollecivisation of an entirely different order.

Enmeshed with the concepts of forgiveness and reconciliation rather than violence, the TRC was the centrepiece of the 'miracle' of South Africa's peaceful transition, credited with helping to avert the bloodbath many assumed would come as apartheid ended (Cassin 2014: 262; Tutu, 1999). At a socio-cultural level, as Richard Wilson (2001:14) demonstrates, the TRC was central to the formation of a post-apartheid national identity 'tied up in how to respond to past human rights abuses,' and in which 'being authentically South African [came] to mean sharing the traumas of apartheid and uniting in the subsequent process of "healing the nation".' From this perspective, while the TRC's importance to South Africa's own post-apartheid imaginary cannot be underestimated, it seems to have little in common with the violent decollectivising strategies outlined above. Nevertheless, I want to suggest that the conjuncture(s) formed between reconciliation, human rights, and identity hold the key to understanding the TRC as a different paradigm of decollectivation, one whose appeal is the affirming language of rights which, through forms of ethical and moral recognition, performs the necessary work of dissembling South Africa's apartheid-era collectives, making way for neoliberalism.

To develop this argument, the article first explores the neoliberal contours of South Africa's transition by contextualising existing work on South African neoliberalism within insights taken from critical neoliberalism studies. It then develops an account of the TRC as a strategy of 'reconciliation' that emerged within the constraints of neoliberal transition. The TRC's 'neoliberal reconciliation', I argue, rests on the use of human rights frameworks and discourses to re-articulate the past as a conflict marked by physical violence. Drawing from the critical human rights scholarship addressed above this will be first understood as an attempt to exclude socioeconomic issues in ways that allowed the process of neoliberalisation to go unquestioned. Going beyond this critique, the article then draws from critical neoliberalism studies to argue that the TRC's practice of reconciliation also fostered subjective transformations capable of performing the work of decollectivisation. Concluding its account, the analysis shows this process at work both in TRC hearings and in media broadcasts of the Commission's work which cultivated an ultimately thin and individualising 'community of emotions.'

\section{South African Neoliberalism}

While the 'neoliberal' character of post-apartheid South Africa is well established (Bond, 2014; Narsiah, 2002; Satgar 2012), the literature could benefit from a closer engagement with critical neoliberalism studies. Many accounts of South African neoliberalism understand it simply as 'market policies' taking place in the delimited arena of the economy. In this account, South Africa neoliberalism emerged out of the transition through the 1996 Growth, Employment and Redistribution (GEAR) macroeconomic strategy, which oriented the economic aspects of the transition towards fiscal discipline, privatisations, and market deregulation. As Sagie Narsiah (2002) has shown, the trajectory embarked upon through GEAR has led to the privatisation of utilities, the cutting of subsidies, the sale of state housing stock, and the outsourcing of public transport to private companies. Furthermore, this has also meant the use of 'market solutions' as the primary vehicle for remedying the iniquities of apartheid. Land 
redistribution, for example, was handled on the basis of a 'willing seller, willing buyer' principle, which guaranteed that land would only be distributed through voluntary market exchanges (Muiu 2008: 156).

These accounts cleave the economic from the social by connecting South African neoliberalism to objectives pertaining solely to the former. For example, Vishwas Satgar's political economy of South Africa's 'Afro-Neoliberalism' emphasises that the objective of the transitional economic programme was largely geared toward integrating the South African state into 'global financial, production and trade structures,' (2012: 56). Consequently, the proliferation of initiatives such as Black Economic Empowerment (BEE) and interrelated Small and Medium Enterprise (SME) programmes, which purportedly 'uplift and empower' individuals by developing their entrepreneurship skills (Rajak 2008), are understood as separate from and subordinated to other objectives such as integrating South Africa into the global economy.

Insights from critical neoliberalism studies provides additional coherence to an analysis of South African neoliberalism by recasting the transition as a strategy concerned with transforming the 'social' rather than simply the realm of 'economic policy' as an independent sphere. From this perspective, South Africa's neoliberal transition was an economic programme which aimed to introduce a new way of governing subjects through the market by encouraging them to both understand and conduct themselves as competing enterprises. In this sense, objectives like integrating South Africa into global markets are not ends in of themselves; rather, they sit alongside BEE and SME initiatives as tactics through which market structures are constructed and regulated to 'govern' the conduct of subjects.

For my purposes, the value of this approach is that it illuminates the way in which economic policies are brought to bear upon 'the social' and the subject, demarcating the latter as a terrain of investigation where the still latent relationships between neoliberal transition and the TRC might become visible. The argument to be presented here is that where South African neoliberalism attempts to produce the subject as an enterprise the TRC performs the correlative and necessary political work of decollectivisation that prefigures and supports this project. To arrive at this conclusion, however, it is first helpful to understand how the TRC emerged within, and as a product of, the neoliberal constraints that were placed upon the transition.

\section{'Negotiated Transition' and the TRC}

The neoliberal transition and the TRC emerged as entangled products of a negotiated settlement between the racist Apartheid regime and the liberation movement(s), which paved the way to the post-apartheid era. As Mueni wa Muiu (2008: 108) demonstrates, apartheid was a state formation that organised the striations of the economy across racial lines, forging class alliances between white workers, farmers and industrialists who shared the spoils of exploiting the black African majority. This conjuncture was fiercely defended by its security apparatuses, the South African Police Force (SAP) and the South African Defence Force (SADF). Against the apartheid state, resistance was organised around several movements, most prominently the African National Congress (ANC) and its Freedom Charter, as well as union organisations. At first, resistance to apartheid was organised by the principle of non-violence, but by the mid-1980s the liberation movement had engaged in a violent struggle to overthrow the apartheid regime and establish a new 
society. Struggle, at times marked by terrible violence and unconcerned with the trauma(s) it caused, attempted to overcome collective injury (socioeconomic subjugation) with a form of transformative collective justice (redistribution).

By the early 1990s the combination of armed resistance and a crippling economic crisis compounded by international sanctions forced the ruling National Party to negotiate the end of apartheid (Muiu 2008: 127-128). But this was not an all-out victory for the liberation struggle; the continuing power of the SAP and the SADF foreclosed attempts to address the previous regime in a way which might have exacerbated the Afrikaners (Boraine, 2000: 143). While this would preclude the possibility of prosecuting leading members of the apartheid regime for their role in the past (van Zyl, 1999), it meant, above all, that the price to be paid for negotiation was the recognition of existing white property rights and the orientation of the economy around neoliberal policies designed to bring development through growth rather than redistribution (Frederickson, 1997: 146), nullifying the promise of the Freedom Charter.

The TRC responded to these dynamics, not only as an alternative to Nurembergstyle tribunals that may have caused more bloodshed (Boraine, 2000), but also as a way of addressing the necessities of nation-building and broader questions of justice at a time when socioeconomic redistribution was off the agenda. The economic concessions given to the Afrikaners necessitated an emphasis on democratic reform to the political system over the struggles against socioeconomic exploitation. Accordingly, as Wilson (2001:1620) argues, 'legal-technical mechanisms' rather than economic redistribution would be the vehicle for social transformation, meaning that 'the importance of legitimate legal institutions [took] on an even greater significance,' than in other transitions. Wilson argues that the TRC became strategically useful for this aspect of nation-building insofar as it enacted the legal ritual through which the legal order of the post-apartheid state was legitimised. Indeed, by staging the moral and legal authority of the new state, the TRC conferred legitimacy on the rule of law as the locus of social change at a time when neoliberal transition disbarred economic transformation.

Crucially, the TRC achieved this not by emphasising its own pragmatism or proceduralism but, as Robert Meister (2011: 51-82) shows, by developing a new concept of 'justice', one which could substitute for the now unrealisable objectives of the liberation struggle by enacting 'a backward-looking logic of having won that could supersede the [now unrealisable] forward-looking goal of winning,' (51). For Meister, the TRC delivered 'reconciliation-as-justice', which articulated 'reconciliation' as a 'moral (and not merely political) imperative' that is equal to and must ultimately supersede the concept of justice-as-struggle. Undoubtedly, what Wilson (2001) understands as the fusion of a 'religious-redemptive paradigm' and the concept of ubuntu, a Xhosa expression associated with community, reconciliation and the rejection of revenge, contributed to the public legitimation of the TRC as reconciliatory justice. These discourses, which circulated widely during the transition, valorised the TRC simultaneously as a distinctive and importantly 'Africanist' model of justice (12-13), and, by connecting reconciliation to Christian notions of redemption and forgiveness, as morally superior to retribution and revenge (109).

Reconciliation was both explicitly legitimised in opposition to retributive justice and, more implicitly, against forms of socioeconomic justice that would require apartheid's 'beneficiaries' to relinquish their wealth and thus transgress the cardinal laws of the market. As Meister (2011: 51) argues, justice-as-reconciliation staged a 'moral 
victory' over apartheid that sidestepped these claims through a paradigm which, as I will demonstrate shortly, enabled both Black South Africans and the regime's beneficiaries to participate as equals and to reach a 'consensus that apartheid was an evil that must never be repeated.' But while Meister's argument begins to frame the import of the TRC within the compromises of neoliberal transition, a clearer understanding of this reconciliation strategy, as well as its political consequences can be achieved through a closer examination of its materiality, which I turn to now.

\section{The TRC-as-Reconciliation: A Human Rights Narrative for South Africa}

The TRC was organised around the assumed relationship between truth-telling and reconciliation. This is reflected in Tutu's foreword to Volume 1 of the TRC report (1998: 18 ) in which he argued that 'it is only on the basis of truth that true reconciliation can take place.' In practice, the conceptual linkage between truth and reconciliation revolved around the production of a shared, national narrative that provided 'healing' by addressing the 'trauma' of the past. Whilst the concepts of healing and trauma usually pertain to the psychological processes of individuals, the TRC redeployed them to describe a process for the nation. Moon (2009: 72) has shown that the purported efficacy of transitional narrative-making and healing rests on an 'anthropomorphised' and 'psychologised' concept of the nation, which assumes that post-conflict societies 'are "traumatised" and require therapeutic management if conflict is to be ameliorated.' In this schema, the production of narrative was supposed to heal national trauma by providing a 'symbolic closure,' so that the trauma was 'no longer seen as unfinished business,' (Hamber and Wilson 2002: 5).

Fulfilling this objective was predicated on the mass participation of South Africans. Reconciliation thus centred upon two practices designed to extract and synthesise the testimonies of individuals, which were considered innovative at their time. Firstly, the cornerstone of the TRC was its so-called 'victim hearings', which enabled human rights victims to participate in 'truth-telling' by testifying in mobile and diffuse public hearings that took place across South Africa. The public hearings enabled victims to explain what had happened to them, to name their abusers and, following that, to seek compensation through the TRC's reparations programme (TRC, 1998: 53-54).

Secondly, the TRC held public hearings for the disclosure of confessions by perpetrators of human rights abuses. This was facilitated by the decision to 'individualise' amnesty applications for perpetrators of human rights violations instead of granting blanket amnesties for political organisations. By the time of the transition, As Jeremy Sarkin (2004) shows, amnesty policy was legislatively tied to the TRC, which could grant amnesty to perpetrators on the condition that they gave a full confession of their crimes and that these crimes were committed in the fulfilment of a political objective (TRC, 1998: 52-54), a criterion used to distinguish apartheid crimes from 'ordinary violence'. In this way, perpetrators were coaxed into 'truth-telling' through an approach that simultaneously 'dangled the carrot' of amnesty and threatened perpetrators with 'the stick' of prosecution (ibid). Even if the amnesty process was fraught and unevenly applied (Sarkin, 2004: 181-189), it was essentially leveraged to elicit the truth about apartheid-era violence from its perpetrators.

These hearings collected individual truths into a shared narrative of the past as a matter of national healing. As Brandon Hamber and Richard Wilson (2001: 1-2) argue, 
the TRC facilitated 'a common and shared memory, and in doing so create a sense of unity and reconciliation,' and created 'a common identity as a traumatised people,' through which 'the country can, at least ideally, move on.' Consequently, the TRC is animated by a tension between the individual and the project of nation building. As Andrea Lollini (2006: 125) argues, individuals had to participate in "the construction of the "collective truth", saying "the same thing", creating homology of the visions of the past.' This tension was 'mediated' by the TRC which developed a set of practices that utilised these individualised experiences, shaping, managing and aggregating them that they 'spoke' as part of a coherent national narrative.

Above all, successfully mediating between the individual and 'the whole' was dependent on utilising human rights discourses to synthesise diverse individual experiences into a coherent narrative about the past. Moon (2008: 49) has noted that the TRC used the legal framework of rights as a "coding frame", "to systematically order events into a taxonomy of violations, in order to quantify and attribute human right abuses.' Using a Foucauldian framework, Moon understands this process as a set of discursive practices, which 'constitute their objects of enquiry rather than the object of enquiry being prior to the discourses that 'contain' them.' Moon's fundamental insight is that human rights discourses didn't simply interpret individual experiences so much as constitute them as objects of knowledge. In this way, individual acts of violence were constituted as, and subsequently grouped into, distinct categories of rights abuses such as 'Killing' or 'Torture'. The effect was to make testimonies commensurate and analysable as patterns of abuse.

Importantly, through these practices, human rights became the primary discursive regime in which the truth about the past could be articulated and disclosed. The effect was that the history of apartheid became a history of human rights abuses, resulting in the reconfiguration of 'apartheid' as the signifier for a period of intense physical violence. Each statement and public testimony established one of many facets of apartheid as a history of largely physical violence, which blighted the lives of South Africans. The TRC knitted these experiences together to create a narrative of apartheid defined by the proliferation of rights abuses.

The discursive constraints of the Commission's rights framework had several politically important effects upon the definition and meaning of apartheid. Most obviously, the legal framework of human rights defined the grid of intelligibility through which the TRC included certain events and excluded others that could not be readily submitted to the individualising logic of legally defined perpetrators and victims. For example, Rosemary Nagy (2004: 13) points out that the Commission was 'unable to treat institutionalised racism, which affected some 32 million people as groups, as a gross violation.' This problem is exemplified by the fact that while acts of arson carried out against individuals' property were included as cases of "Severe Ill Treatment", the TRC omitted the loss of home through forced removals that affected around 3.5 million people as groups (ibid.).

Furthermore, the 'neutral' legalism of human rights meant that the TRC was designed to 'even-handedly' investigate human rights abuses from all sides, including ANC abuses against white Afrikaners and so-called 'black-on-black' violence (TRC, 1998: 65-66). Accordingly, human rights provided a conciliatory framework in which individuals from all sides of the struggle could both be formally recognised as victims and denigrated as rights-abusers. This shift had political consequences. In recent years, TJ 
scholars have noted that there is a tendency for human rights processes to simplify the complexities of violence into a simplistic moral binary between 'good' or 'innocent' victims and 'evil' perpetrators (McEvoy and McConnachie, 2012; 2013). As Erica Bouris (2007: 139-186) notes, the TRC harboured a specific instantiation of this problem, reifying 'apartheid' within a victim-perpetrator binary, and transforming 'complex political victims', who may simultaneously be perpetrators, and/or beneficiaries, into morally acceptable innocents. But crucially, in doing so, the process also flattened the disparities between the then-ruling white and the subjugated non-white population by rendering both sides into formally equivalent (human rights) victims and perpetrators whose disparate socio-political positions could no longer be properly recognised.

This process of 'flattening' was further compounded by the conditions attached both to the amnesty process and the formal recognition of victims. On the one hand, amnesty could only be granted to perpetrators whose crimes were committed within the parameters of a political objective defined in the following formulations: the act being commanded, planned or committed by a supporter or member of a publicly known political organisation; or, a member of the state or of the security forces of the state, but crucially only insofar as 'the act in question must have been committed with the objective of countering or otherwise resisting the said struggle' (TRC, 1998: 82-83). On the other hand, gaining 'victim status' also depended on the offence meeting the same criteria of a political objective, and victim statements 'were turned down $[\ldots]$ because the matter could not be proved to be politically motivated,' (TRC, 2003: 1). Consequently, human rights violations could only be considered part of the narrative of 'apartheid' if they could be connected to formal structures of political organisations and party politics to the obvious exclusion of everyday violence and racism. In effect, the Commission composed apartheid as the signifier for a civil war between equally balanced sides. It transformed apartheid into a partisan conflict in which neither side could make absolute claims to ethical superiority; after all, both were guilty of rights violations. Indeed, the TRC demanded the confessional of the ANC's 'taintedness' as much as it did of the National Party and state forces.

In a very real sense, the value of this narrative vis-à-vis reconciliation is related to the pragmatics of the transition. Members of the liberation struggle and the apartheid regime (as well as their supporters and beneficiaries) were recuperated and reconciled as both innocent victims and morally compromised perpetrators, a strategy that was successful insofar as it uncoupled notions of good and evil from a history of exploitation and recast them through a moral denunciation of physical violence. As Meister (2011: 69) laments, the TRC's project of reconciliation was one of 'reducing the scope of social injustice to pain and the scope of political evil to cruelty' as an attempt to persuade 'the beneficiaries and the perpetrators of apartheid that the past was evil.' Nevertheless, this pragmatics cannot be detached from a politics that emerges from within it, one that I will now explicate.

\section{A Neoliberal Miracle?}

Politically, this narrative re-writing might be understood as an example of the ways that human rights frameworks can exclude and obfuscate the structural violence that lies behind the phenomena they describe (Franzki \& Olarte, 2014; Marks, 2013; Miller, 2008). The Commission's narrow focus on individualised and physical violence meted 
out by some beings against others obscured apartheid's structural violence(s) with important political effects. In general, the TRC confounded attempts to grasp apartheid as a societal form where subjugation was a socioeconomic system that controlled the everyday lives of non-white South Africans. Constrained to focus on individualised instances of the phenomenal and the spectacular, the structural and the everyday were obscured form view; the TRC's emphasis on human rights made it difficult to accommodate them.

Certainly, this problem is compounded by the ethics of human rights, which, as Alain Badiou (2001: 9) argues, subdues and supplants 'the political' as a consequence of its interventionist logic which demands ethical action. For Badiou, rights universalise the suffering bodies of victims so as to activate the indignation of a spectator who, in seeing their suffering, 'knows it must be stopped by all available means.' Consequently, the selfevident urgency of human suffering is elevated to the detriment of the political circumstances in which violence takes place. In the case of the TRC, the ethics of rights was structurally guaranteed by the statutory obligation to acknowledge violations on all sides. The TRC marginalised and thus de-politicised the liberation struggle through an ethics that gave equivalence to its partisans and those of the apartheid regime who were both equally compromised by their cruelty.

If, as Wilson (2001) argues, the TRC occupied a central position in South Africa's transition, both by legitimising the post-apartheid legal order and by constructing a shared national identity, then the effects of its narrative are not inconsequential but must be considered in terms of their broader contribution to the (neoliberal) transition. The central point, then, is not only that what might be called the 'socio-economic' is excluded from the discussion but that this omission had broader socio-political consequences for the transition.

Gready and Robins (2014: 342-349) have argued that in focusing on civil and political rights abuses, TJ mechanisms have failed to make broad and meaningful policy demands regarding socioeconomic justice. Accordingly, TJ has suited a neoliberal agenda that rejects redistributive policies in favour of a market-based paradigm, allowing enduring poverty and entrenched inequalities to continue. For Gready (2011: 210-224), this problem was reproduced in South Africa where the Commission not only failed to confront the socioeconomic foundations of apartheid and its legacies (including 'the market'), but provided beneficiaries, including business, with 'narratives facilitating selfexculpation rather than self-recognition ("we did not perpetrate gross human rights violations as you interpret them," "we are all victims,").'

By bracketing off political concerns about structural inequality in favour of an ethical rejection of violence, the TRC reconciled South Africa to a new social unity by polarising the entire social body against a version of apartheid that provided minimal disruption to the significant constraints placed on the transition. Precisely because apartheid no longer signified political oppression and struggle but the ethical problem of a violent conflict, dealing with the past required denouncing apartheid only in so far as it was violent. The TRC's narrative engendered a conciliatory consensus that could assuage the transition without having to properly attend to the very structures that undergirded the 'conflict'. Reconciliation-as-justice did not address the racial iniquities of apartheid but tacitly enabled them to continue within the parameters of a market-based economy (see: Finn et al., 2011). 
In his own analysis of the South African transition, Meister (2011: 69) has put this in even more political terms by reading the TRC through the conceptual framework of 'counterrevolution'. For him, the Commission's obfuscation of the socioeconomic oriented the project of reconciliation towards a form a pseudo-transcendence that aided the counterrevolutionary struggle against liberation even as it claimed to overcome it. Here, reconciliation was understood to have overcome the past through a 'thin' consensus that it was evil, but only in order that 'victims of the old regime let its beneficiaries keep their gains.' Meister's political reading of the TRC is one in which an 'overcoming' is staged through human rights discourses that avoid questions of socioeconomic inequality precisely in order that it can continue.

But this political reading must be pushed further. After all, the transition was not simply a counterrevolutionary project that enabled the continuation of white rule; it totally reconfigured South Africa's economic model, from racialised capitalism, in which 'white' and 'black' were operative categories of accumulation and exploitation, to a neoliberal economy concerned with governing subjects by making 'a social fabric in which precisely the basic units would have the form of the enterprise' (Foucault 2008: 148). Even if one agrees with Meister that it has allowed racially segmented inequality to continue, it is necessary to build on this critique and articulate how the TRC might serve a more specific, productive function for neoliberalism.

A crucial point in this regard is the Commission's valorisation of suffering bodies as 'human rights victims', which rearticulated the concept of victimhood itself from socio-economic exploitation to physical cruelty. Moving from a socio-economic concept of the victim (a collective) to a suffering body (an individual) dissolves more collectivised and communitarian forms of social belonging and solidarity, in favour of valorising the individual as the privileged locus of understanding and action vis-à-vis apartheid. This move framed apartheid not as systemic violence(s) but as a multidirectional contagion in which violence emanated from everywhere. Apartheid was presented as a crisis with the potential to affect everybody as individualised suffering bodies. The narrative dissembled battle lines and collective associations by constructing an image of the past that denounced physical violence against all individuals. In doing so, the TRC sketched out the conditions for a future in which collective identity organised around socioeconomic and political struggle is no longer relevant insofar as society becomes the open plane of universalised competition.

It is precisely here that the connections between the practice of reconciliation and the tactics of decollectivisation central to the neoliberal project emerge. Just as the projects of Thatcher and Pinochet used different but ultimately violent tactics to dismantle the collective economic and political institutions and movements, through the conciliatory and ethical discourse of rights, the TRC fostered a discourse that took aim at the primarily political relations of black South Africans, as organised through the ANC and other parties. By traversing the path from socio-economic victim to suffering body, the TRC provided a mechanism of decollectivisation that made way for the individualising economic strategies of post-apartheid neoliberalism.

Crucially, this work of decollectivisation must be understood as a process which takes place within the order of subjectivity. For just as neoliberal governing produces an entrepreneurial subjectivity, the Commission's complimentary process of decollectivisation also requires practices capable of individualising subjects. This being the case, this analysis now explores the way in which individualisation was achieved 
through the production of subjectivities interrelated with human rights victimhood. For reasons of both clarity and space, I focus on two central practices through which politically important subjectivities were produced: firstly, the hearings in which speaking subjects were individualised as victims, and, secondly, through the broadcasting of the hearings through the mass media which, in encouraging the South African public to become moral spectators, had a secondary individualising effect on the public as a whole.

\section{Victim Subjectivities and the Community of Emotion}

In the History of Sexuality, Foucault (1998: 58-63) famously demonstrated how truthtelling practices such as confession produce subjects by entering them into discourses and thus giving them positions through which they can speak truthfully about themselves. Drawing on this idea, Moon (2008: 51) has read the TRC as a kind of confessional practice in which 'truth-telling' produces individuals as victims and perpetrators in the moments where they are incited to speak as such. Consequently 'perpetrators appear to collude in their own subjection as perpetrators by performing a public ritual of confession to the TRC - as indeed do victims collude in their own subjection as victims by 'bearing witness' to suffering.' Such a process, where one's life experiences are given meaning in the wider context of South Africa, is also one in which individuals are incited to understand themselves as the subject of this context. Individuals were transformed into victims through their interactions with the TRC victim hearing process, which incited them to speak and to articulate themselves as such.

The political expediency of the subjectivation practices Moon delineates can be developed by placing them within the framework sketched out so far. From this perspective the production of victim subjects served as a form of political de-activation, which can be comprehended through the logic of the 'reconciled' victim outlined by Meister (2011: 53). For Meister, the individual that consents to the logic of human rights - rather than understanding apartheid primarily as a structure of economic exploitation becomes a 'reconciled victim', accepting their only victory over apartheid as a moral recognition that the past was evil by the regimes' perpetrators and beneficiaries. Becoming a victim satisfies the individual's desire for recognition, but comes at a cost. For Meister, the offer of moral recognition provides a subject position that 'reverse[s] the logic of consciousness-raising through which exploited individuals may become revolutionaries.' That is, the recognition and valorisation of physical pain and suffering fosters a new subjectivity - the human rights victim - that supersedes and displaces politically conscious and collectively-minded liberation subjectivities.

Gerald Thebe's victim hearing is a good example of this process. Thebe's hearing focused the 'severe ill-treatment' he suffered after being arrested and tortured for organising students to take political action. Thebe's story is caught in the tension between the political nature of his activities and the physical violence that took place as a consequence. And yet, through the TRC process Thebe is compelled to disclose the truth purely as an experience of violence against his body. This is highlighted by the commissioners' line of questioning, which is primarily concerned with the torture Thebe suffered:

DR RANDERA: You also mentioned that you were hit with an iron bar on your head. 
MR THEBE: On the head ja, at Compol building.

DR RANDERA: That's all I want to ask.

DR BORAINE: Are there any other questions?

MS SOOKA: I notice from your statement you said that the beating lasted for four weeks, did they kick you and beat you up every single day?

MR THEBE: Ja they were beating us every day.

$$
[\ldots]
$$

MR MALAN: The Act says that we must find that people who are victims in terms of a very specific definition and I think this may relate to a definition of severe ill-treatment. Can you please explain to us, or tell us what was the nature, and I know it's difficult, the nature of the injuries that you sustained through the assaults?

(Victim Hearing of Gerald Thebe, 1996)

Thebe's truth was only validated as an experience of suffering. The TRC did not ask Thebe to address himself as a subject of political struggle, or seek to understand his experience in political terms, but rather through the de-politicising and individualising logic of human rights. The politics of struggle gives way to the recognition of individual suffering.

Importantly, the truths constructed inside the hearing process were publicly disseminated through the mass-media. Testimonies became images of suffering to be viewed by the whole nation, a practice intended to produce its own subjective effects. Scholars have already pointed out that the media was crucial to the success of the TRC (Krabill, 2001; Verdoolaege, 2005). As Catherine Cole (2010: 7) rightly points out, while most scholarship tends to focus on the Commission's report as the 'preeminent representation' of its work, the TRC was primarily experienced by South Africans through 'the representation of hearings via the media.' The mediatisation of the Commission thus played a central role in ensuring the process 'pierced the consciousness of nearly all South Africans,' (Gibson, 2006: 416).

In disseminating the hearings through broadcast media, Ron Krabill (2001: 568569) argues the TRC became a 'media event' through which the TRC could command attention 'universally and simultaneously.' For Krabill (2001: 570) media events provide 'a special role in fractured societies by providing a common experience that transcends the daily divergence of our lives.' For Krabill, however, this is more than simply broadcasting an image that individuals can hold in common. Rather, the media event has a definitional ambition; it 'compels us to discuss a common issue, sometimes even providing a common terminology with which to discuss it across large populations'. As Krabill points out, prior to the TRC the term 'gross violations of human rights' would have hardly been given public usage, 'yet now it is ubiquitous.' In other words, the TRC, as a media event, brought communities together by providing images and lexicons with which they could interpret and discuss a specific version of the past. 
Pulling out the more political implications of the "media event", I want to think about the TRC's mediatisation as a strategy designed to induce specific subjective responses. Principally, the mediatisation of the hearings fixed them within a logic of ethical spectatorship that Badiou (2001: 9) traces in his critique of human rights. It transformed the South African public into spectators who must "bear witness" to suffering must resolve to stop the suffering of victims by all available means. This form of "bearing witness" is made up of two components. It first requires the spectacle of the body suffering to ' $[\ldots]$ activate the sympathetic and indignant judgement of the spectator.' In this respect, bearing witness is initiated by the spectacle of the suffering body and affective responses of horror and sympathy it is alleged to produce. This was certainly central to the mediatisation of the TRC. Through an analysis of tv and radio broadcasting in South Africa, Annelies Verdoolage (2005: 188) concludes that the media turned the TRC into a public spectacle specifically organised around 'the trauma of the individual victim.'

Special Report, an in-depth weekly programme on the TRC hearings broadcasted by the South African Broadcasting Company (SABC), serves as a case and point. Cole (2010: 109) has argued that the tone and style of the programme, particularly its intercutting of victim testimonies with the reactions of live audiences at the hearings, was designed to implicate viewers as witnesses to suffering. Indeed, as the then Editor in Chief of SABC News, Joe Thloloe (1998: 53-54) notes in his account of the development of Special Report, the programme was developed with a clear editorial line organised around suffering: it 'was not about politicians - it was about the way that ordinary men, women and children felt about the horrors of apartheid.' Even when sensational tales of fall-outs between TRC commissioners could have been the focus of the programme, Special Report 'concentrated on telling the stories of the victims of human rights violations.'

Importantly, the intertwined production of horror and sympathy is the precondition for the second component of bearing witness: a resolution to act grounded in the ethics of human rights (Badiou, 2001: 9). In the case of the TRC, the spectacle of suffering was intended to evoke the spectator's sympathy as the first step in their resolution to reconcile to both alleviate suffering and prevent its future repetition. Perhaps Tutu was closest to explaining the TRC's utilisation of public sympathy towards the end of a hearing in August 1996 at Cape Town. I quote it at length because it alludes to the value of making a public spectacle of the suffering body:

we hope $[\ldots]$ so much of this pain and anguish might be transformed as it contributes to the growing together of our people and the reconciliation of those who for so long, have been alienated from one another. (quoted in Victim Hearing of Kulekile Simon Kuwete, 1996)

As Tutu suggests, the TRC could produce emotional responses to the stories of suffering bodies that served its reconciliatory end. It was able to induce generalised affects - horror and sympathy - as a catalyst for reconciling the nation in a shared belief that the past was an evil (of torture and cruelty) never to be repeated. This is borne out by James Gibson's empirical research on the TRC's effect on South Africans (2004), which finds that its mediatisation of suffering contributed to fostering a recognition amongst ordinary South Africans that all sides 'did horrible things', and '[forced] people to acknowledge the “other side" was unfairly victimised,' (414). 
In the Administration of Fear, Paul Virilio (2012: 30) provides a short exposition on what he calls the 'informational bomb' produced by instantaneous communications and transmission of information possible through media technologies. Like the fear of nuclear annihilation of the Cold War era, Virilio insists these technologies play 'a prominent role in establishing fear as a global emotion because it allows the synchronisation of emotion on a global scale.' Importantly, the process of synchronisation is generative and enables a 'community of emotions' to be constituted through 'a communism of affects.' Virilio's terminology can be deployed to usefully describe the TRC's communication of the stories of suffering bodies, which was designed to effectuate a similar kind of synchronisation: a community of emotions based on a shared horror at the past, and a sympathy for its (human rights) victims.

Virilio (2012: 31) argues that the informational bomb enables a transition to a community of emotions from a 'community of interests shared by different social classes.' His point is that while the latter produced a quasi-Habermasian democracy of opinions the former has destabilised 'the time reserved for reflection in favour of the conditioned responses produced by emotion.' With some slight modification his argument is compelling here. If the injustices of the apartheid regime created a schism between two collective identities based on their socio-economic interests, then the TRC enabled the social body to transcend this schism by harmonising affect. By fostering synchronised, simultaneous, and immediate emotional response to suffering, the Commission created a singular community of emotions based on horror and sympathy for victims. The transition from interest to emotion that Virilio traces is mirrored in politically useful ways by the work of the TRC.

The expediency of this community of sympathy was that it encouraged non-white subjects, and not just those testifying before the Commission, to traverse the path from collective, socio-economic victimhood to accepting that the real victim of apartheid was the individual suffering body. Furthermore, because suffering bodies are not striated by conditions of race, colour, socio-economic position, or political affiliation, black and other non-white South Africans enjoined with the apartheid regime's partisans and its passive beneficiaries as a community of emotions, who were able to identify and sympathise with physical suffering 'wherever it occurred' (TRC, 1998: 65). In other words, 'through the act of bearing witness' all subjects were called to suspend other forms of subjectivity, other kinds of political activity and agency, and 'to identify with individual victims (or at least their pain) and also to see themselves as victims,' (Meister, 2011: 28). As a result, the transformation of victimhood to the suffering body is attended to at a subjective level through the synchronisation of affects engendered by spectacles of suffering.

Importantly, this new 'community of emotion' should not be confused for a substantively communitarian identity or a social solidarity. For this process venerates and valorises the individual body as the site of the nation's new ethical imaginary. It delineates a new social space in which the integrity of individual bodies must be prioritised over the forging of collective identities to overcome more diffuse, collectively felt, and enduring forms of socio-economic suffering. In advocating this shift, the TRC prepared the way for post-apartheid neoliberalism; it did the necessary work of decollecitivising 'the social', eroding the solidaristic organisation of struggle just as other practices began to produce the entrepreneurial hyper-individualism desired by the neoliberal project. 


\section{Conclusion}

Post-apartheid South Africa has been definitively shaped by two key aspects of the transition. While the GEAR strategy has been important in shaping the nation's neoliberal trajectory, one marked by still growing inequalities, the TRC has played a remarkable role in constructing its socio-cultural identity around notions of reconciliation and human rights (Wilson, 2001). But if at first glance these 'apparatuses' of the transition may seem to have little to do with one another, my argument has been precisely the opposite.

The Commission's shaping of South African socio-cultural identity is deeply connected to the production of a 'social memory' (Hamber and Wilson, 2002) about the past, a narrative through which South Africa's warring factions could come to a consensus both that the past was evil and that all sides could be considered its victims. This narrative identified and valorised the real victim of apartheid, not as the collective body of a subjugated people, but the de-politicised, suffering body of the individual. By transforming the victim into the latter, political questions regarding the struggle against economic exploitation were subdued by an ethics that prioritised the condemnation of all violence as evil. Such condemnation fostered a moral consensus, one that did not contradict the key assumptions of the neoliberal transition but rather allowed the project to flourish largely unquestioned.

Nevertheless, my key argument has been that this narrative was more than a morality tale about the past. In fact, it was effective because it fostered the individualising 'socio-cultural identity' of human rights at the level of subjectivity. While the Commission's truth-telling practices produced individuals as victims by encouraging them to speak as such, the mediatisation of these hearings also encouraged others to bear witness to the images of suffering of bodies. In doing so, the TRC operated on an affective level, producing an emotional consensus organised around individualised forms of suffering. Together, these practices dissembled South Africa's collective identities by creating a community of emotion, drawn together by its sympathy and veneration of victims and their individualised, suffering bodies.

Drawing from the insights offered by critical neoliberalism studies, I have characterised this process as a tactic of de-collectivisation, which, in keeping with other neoliberal projects, accompanies and effectively prefigures the individualising requirements of neoliberal entrepreneurialism. However, the TRC signals an altogether different paradigm of decollectivisation to those often examined by critical neoliberalism scholars, one that is not reliant on a political strategy of confrontation and destruction. Rather, the Commission deployed an ethics of recognition which, through the language of rights, called subjects to abandon collective understandings of injury, justice, and political organisation and to identify with the passive and individualised suffering.

This perspective perhaps sheds light on the ossification of South African neoliberalism in the 25 years since apartheid ended. Neither the staged 'overcoming' of apartheid offered by the Commission nor the neoliberal GEAR strategy adopted by the state have substantially addressed the legacies of subjugation and inequality. With inequality increasing, South Africa's predicament is rooted in the lessening ability for claims of transcendence made by 'reconciliation-as-justice' to feasibly hold together the post-transitional imaginary and the subjectivities it implies. The socioeconomic powder kegs that Muvingi (2009) warned may explode into new rounds of violence in South Africa can no longer be contained by the subjective forms developed to dissipate them during the transition. Indeed, resistances at Marikana and after may signal the reopening 
of South Africa's transitional closure and the re-emergence of socioeconomic victimhood as a fundamental concept within its political landscape.

At the same time, these arguments also have broader implications for human rights and TJ scholarship, and point to the continuing need to develop our understanding of the relationship(s) between human rights and neoliberalism. Since apartheid ended, the forms of victimhood and recognition developed by the TRC represent a mode of addressing the past that has become standard policy as transitions continue to be organised within the constraints of neoliberal globalisation. If the South African case shows that the language of rights can produce passive, individualised forms of subjectivity that tend to dissemble claims for collective justice, then the question whether the human rights project performs a similar function in a diverse number of contexts and through the various mechanisms, legal instruments, and social practices that operate in its name. In this respect, the value of this analysis is that it delineates one approach with which to make these still-latent connections visible and, in doing so, to better understand the limitations of the human rights project.

\section{References}

Alexander, P., Sinwell, L., Lekgowa, T., et al. (2012). Marikana: A View from the Mountain and a Case to Answer. Auckland Park, SA: Jacana Media.

Alston, P. (2017a). The Populist Challenge to Human Rights. Journal of Human Rights Practice, 9(1), 1-15

Alston, P. (2017b). Reply to Dudai and Nagaraj. Journal of Human Rights Practice, 9(1), $25-28$

Arthur, P. (2009). How “Transitions” Reshaped Human Rights: A Conceptual History of Human Rights. Human Rights Quarterly, 31(2), 321-367.

Badiou, A. (2001). Ethics: An Essay on the Understanding of Evil. London: Verso.

Bond, P. (2014). Elite Transition: From Apartheid to Neoliberalism in South Africa (2nd ed.). London: Pluto Press.

Boraine, A. (2000). Truth and Reconciliation in South Africa: The Third Way. In R. I. Rotberg, \& D. Thompson (Eds.), Truth V. Justice: the Morlaity of Truth Commissions. Princeton: Princeton University Press, pp. 141-157

Bouris, E. (2007). Complex Political Victims. Bloomfield, CT: Kumarian Press

Brown, W. (2004). The Most We Can Hope For: Human Rights and the Politics of Fatalism. South Atlantic Quarterly, 103(2/3), 451-463.

Brown, W. (2015). Undoing the Demos: Neoliberalism's Stealth Revolution. New York: Zone Books.

Cassin, B. (2014). Sophistical Practice: Toward a Consistent Relativism. New York: Fordham University Press.

Christodoulidis, E. (2000). Truth and Reconciliation as Risks. Social \& Legal Studies, 9(2), 179-204.

Cole, C.M., (2010). Performing South Africa's truth commission: Stages of transition. Bloomington and Indianapolis: Indiana University Press.

Dardot, P., \& Laval, C. (2013). The New Way of the World: On Neoliberal Society. London and New York: Verso.

Davies, W. (2014). The Limits of Neoliberalism. London: Sage Publications.

Dudai, R. (2017). Human Rights in the Populist Era: Mourn then (Re)Organise. Journal of Human Rights Practice, 9(1), 16-21. 
Evans, M. (2016). Structural Violence, Socioeconomic Rights, and Transformative Justice. Journal of Human Rights, 15(1), 1-20

Finn, A., Murray, L., \& Wegner, E. (2011). Policies for reducing income inequality and poverty in South Africa. In J. Hofmeyr (Ed.), Transformation Audit 2011: From Inequality to Inclusive Growth. Cape Town: Institute for Justice and Reconciliation, pp. 70-82

Foucault, M. (1998). The History of Sexuality: The Will to Knowledge. London: Penguin Books.

Foucault, M. (2008). The Birth of Biopolitics: Lectures at the College de France 19781979. New York: Palgrave Macmillan.

Franzki, H., \& Olarte, M. C. (2014). Understanding the Political Economy of Transitional Justice. In S. Buckley-Zistel et al. (Eds.), Transitional Justice Theories. Oxon and New York: Routledge, pp. 201-221.

Fredrickson, G. M. (1997). The Comparative Imagination: On the History of Racism, Nationalism and Social Movements. Berkely: University of California Press.

Gibson, J. L. (2006). The Contributions of Truth to Reconciliation. Journal of Conflict Resolution, 50(3), 409-432

Gready, P., (2011). The Era of Transitional Justice. Oxon: Routledge

Gready, P., \& Robins, S. (2014). From Transitional to Transformative Justice: A New Agenda for Practice. International Journal of Transitional Justice, 8, 339-361.

Hamber, B., \& Wilson, R. (2002). 'Symbolic Closure through Memory, Reparation and Revenge in Post-conflict Societies'. Journal of Human Rights 1(1): 35-53.

Klein, N. (2007). The Shock Doctrine: The Rise of Disaster Capitalism. London: Allen Lane.

Krabill, R. (2001). Symbiosis: mass media and the Truth and Reconciliation Commission of South Africa. Media, Culture \& Society, 23(5), 567-585.

Lindroth, M., (2014) Indigenous rights as tactics of neoliberal governance: Practices of expertise in the United Nations. Social \& Legal Studies, 23(3): 341-360.

Lollini, A. (2006). The South African Truth and Reconciliation Commission: Establish a New Hypothesis Post Conflict Culture. In C. Demaria, \& C. Wright (Eds.), PostConflict Cultures: Rituals of Representation. London: Zoilus Press, pp. 113-132

Madlingozi, T. (2010). On transitional justice entrepreneurs and the production of victims. Journal of Human Rights Practice, 2(2), 208-228.

Marks, S. (2013). Four Human Rights Myths. In D. Kinley, W. Sadurski, \& K. Walton (Eds.), Human Rights: New Problems, Old Possibilities. Northampton, MA: Edward Elgar, pp. 217-235

McEvoy, K. and McConnachie, K., (2012). Victimology in transitional justice: Victimhood, innocence and hierarchy. European Journal of Criminology, 9(5), 527-538.

McEvoy, K., \& McConnachie, K. (2013). Victims and transitional justice: Voice, agency and blame. Social \& Legal Studies, 22(4), 489-513.

Meister, R. (2011). After Evil: A politics of Human Rights. New York: Columbia University Press.

Miller, Z. (2008). Effects of Invisibility: In Search of the 'Economic' in Transitional Justice. The International Journal of Transitional Justice, 2(3), 266-291.

Mirowski, P. (2013). Never let a Serious Crisis Go to Waste: How Neoliberalism Survived the Financial Meltdown. London and New York: Verso. 
Moon, C. (2006). Narrating Political Reconciliation: Truth and Reconciliation in South Africa. Social \& Legal Studies, 15(2), 257-275.

Moon, C. (2008). Narrating Political Reconciliation: South Africa's Truth and Reconciliation Commisison. Plymouth: Lexington Books.

Moon, C. (2009). Healing Past Violence: Traumatic Assumptions and Therapeutic Interventions in War and Reconciliation. Journal of Human Rights, 8(1), 71-91.

Moyn, S. (2012). The Last Utopia: Human Rights in History. Cambridge, MA: Harvard University Press.

Moyn, S. (2014). A Powerless Companion: Human Rights in the Age of Neoliberalism. Law and Contemporary Problems, 77, 147-169.

Muiu, M. w. (2008). The Pitfalls of Liberal Democracy and Late Nationalism in South Africa. New York: Palgrave Macmillan.

Muvingi, I. (2009). Sitting on Powder Kegs: Socioeconomic Rights in Transitional Societies. International Journal of Transitonal Justice, 3(2), 163-182.

Nagy, R. (2004). Violence, Amnesty and Transitional Law:"Private" Acts and "Public" Truth in South Africa. African Journal of Legal Studies, 1(1), 1-28.

Nagy, R. (2008). Transitional Justice as Global Project: critical reflections. Third World Quarterly, 29(2), 275-289.

Narsiah, S. (2002). Neoliberalism and Privatisation in South Africa. GeoJournal, 57(1), 3-13.

Odysseos, L. (2010). Human Rights, Liberal Ontogenesis and Freedom: Producing a Subject for Neoliberalism. Millennium - Journal of International Studies, 38, 747-772.

Odysseos, L. \& Selmeczi, A., (2015) The power of human rights/the human rights of power: an introduction. Third World Quarterly, 36 (6), 1033-1040

Rajak, D. (2008). 'Uplift and Empower': the market, morality and corporate responsibility on South Africa's platinum belt. In G. De Neve, P. Luetchford, J. Pratt, \& D. Wood (Eds.), Hidden Hands in the Market: Ethnographies of Fair Trade, Ethical Consumption, and Corporate Social Responsibility. Bradford: Emerald, pp. 297-324

Sarkin J. (2004) Carrots and Sticks: The TRC and the South African Amnesty process. Antwerp and Oxford: Intersentia.

Satgar, V. (2012). Beyond Marikana: The Post-Apartheid South African State. Africa Spectrum, 47, 33-62.

Selmeczi, A., (2015). Who is the subject of neoliberal rights? Governmentality, subjectification and the letter of the law. Third World Quarterly, 36(6): 10761091.

Sriram, C. L. (2014). Liberal Peacebuilding and Transitional Justice: What Place for Socioeconomic Concerns? In D. Sharp (Ed.), Justice and Economic Violence in Transition (pp. 27-50). New York: Springer

Thloloe, J. (1998). Showing faces, hearing voices, tugging at emotions: Televising the Truth and Reconciliation Commission. Nieman Reports, 52(4), 53-54.

Truth and Reconciliation Commission. (1998). TRC Report, Volume 1. Available at: http://www.justice.gov.za/trc/report/finalreport/Volume\%201.pdf

Truth and Reconciliation Commission. (2003). TRC Report Volume 7. Availabe at: http://www.justice.gov.za/trc/report/finalreport/vol7.pdf

Tutu, D. (1999). No Future Without Forgiveness. London: Random House. 
van Zyl, P. (1999). Dilemmas of Transitional Justice: the case of South Africa's Truth and Reconciliation Commission. Journal of Internationla Affairs, 52(2).

Verdoolaege, A. (2005). Media representations of the South African Truth and Reconciliation Commission and their commitment to reconciliation. Journal of African Cultural Studies, 17(2), 181-199

Victim Hearing of Gerald Thebe. (1996, April 29). GO/0091. Available at: http://www.justice.gov.za/trc/hrvtrans/methodis/thebe.htm

Victim Hearing of Kulekile Simon Kuwete. (1996, August 6). CT/00827. Available at: http://www.justice.gov.za/trc/hrvtrans/helder/ct00827.htm

Virilio, P. (2012). The Administration of Fear. Cambridge, MA and London: Semiotext(e).

Wilson, R. A. (2001). The Politics of Truth and Reconciliation in South Africa: Legitimizing the Post-Apartheid State. Cambridge University Press.

Wilson, R. A. (2006). Afterword to "Anthropology and human rights in a new key": the social life of human rights. American Anthropologist, 108(1), 77-83. 